\title{
有孔ケーソンを利用した 空気タービン式波力発電装置の開発
}

木原 一禎 ${ }^{1} \cdot$ 増田 光一 ${ }^{2} \cdot$ 下迫 健一郎 $3 \cdot$ 大澤 弘敬 $4 \cdot$ 居駒 知樹 ${ }^{2}$ 金谷 泰邦 ${ }^{5} \cdot$ 永田 $\quad$ 修一 ${ }^{6} \cdot$ 細川 恭史 1

1正会員 エム・エムブリッジ株式会社（テ103-0006 東京都中央区日本橋富沢町9-19） E-mail: kihara.kazuyozhi@mm-bridge.co.jp,hosokawa.yasushi@mm-bridge.co.jp

${ }^{2}$ 正会員 学校法人 日本大学 理工学部教授 海洋建築学科 （干274-8501 千葉県船橋市習志野台7-24-1）

E-mail:masuda.koich@nihon-u.ac.jp, ikoma.tomoki @nihon-u.ac.jp

3正会員 国立研究開発法人 港湾空港技術研究所（†237-0061 神奈川県横須賀市長瀬3-1-1）

E-mail:shimosako@pari.go.jp

4正会員 国立研究開発法人 海洋研究開発機構（下237-0061 神奈川県横須賀市夏島町2-15)

E-mail:osawah@jamstec.go.jp,tsuyoshim@jamstec.go.jp

${ }^{5}$ 正会員 東亜建設工業株式会社 土木事業本部 （率163-1031 東京都新宿区西新宿3- 7 -1）

E-mail:y_kanaya@toa-const.co.jp

${ }^{6}$ 正会員 国立大学校法人 佐賀大学海洋エネルギーセンター教授（テ690-8502 佐賀県佐賀市本庄末 1 )

E-mail:nagata@ioes.ac.jp

これまで，30 年以上の研究実績がある振動水柱型空気タービン方式 (Oscillating Water Column:以下 OWC) に着目し, 従来に比べて高効率な発電装置の開発を行っている. 研究コンセプトは, 発電装置を既設の防波 堤や護岸に後付けで据えることで建造費用を抑える事ができる安価なシステムである．OWC 発電装置は， 水面変動を往復気流に変換し, 空気流で発電タービンを回転させる. 発電部が水上にあるため, 維持管 理が容易であり，既存の防波堤，護岸などを利用して後付けでユニットを設置することで，建造費を抑 えることができる，既存施設を利用するため，沖合に独立して係留する場合と異なる課題を検討した。 本稿では，酒田港で実証実験を行っている消波ケーソン(有孔ケーソン)に設置した事例について紹介する.

Key Words : oscillating water column,wave power extracting breakwater,projecting wall,Sakata port

\section{1. 研究の概要}

開発する発電装置は，図-1に示すような構造である. 従来のOWC (Oscillating Water Column) にPW(プロジェク ティングウォール)を設置する(以下 PW-OWC)ことで, 一次変換効率を従来のOWCに比べて1.5倍程度効率を向 上させている12)．既設の防波堤や護岸に後付けのユニッ トタイプとし，建造・設置コストの低減化をはかり，発 電単価40円/kWh以下を目指している.

本稿では，平成23年からこれまで開発を行い，既に検 証済みであるPW-OWC波力発電装置の安全性にかかる 耐波性能の概要について報告する。加えて，平成26年 度から取り組んでいる, 酒田港内の有孔ケーソンを活 用した実海域実証実験に関するこれまでの成果を報告 する.

\section{PW-OWCの概要}

本装置のイメージ図を図-1に示す。発電装置では，波
エネルギーをOWC空気室内で上下運動に変換し（一次 変換），背後の小径孔より流出入される圧縮空気により タービン・発電機を回転させること（二次変換）で発電 を行う。

また，二次変換の変換効率の向上については，新たに 開発した衝動タービンを使用することで，従来波力発電 に多く使用されているウェルズタービンに比べて1.2倍 程度効率を向上させる ${ }^{1)}$. 本装置は，海岸線の防波堤や 護岸に設置されることを想定しているため，エネルギー 変換効率や発電コストの他, 公共構造物として, 安全性 について特に慎重に検討する事が必要である.

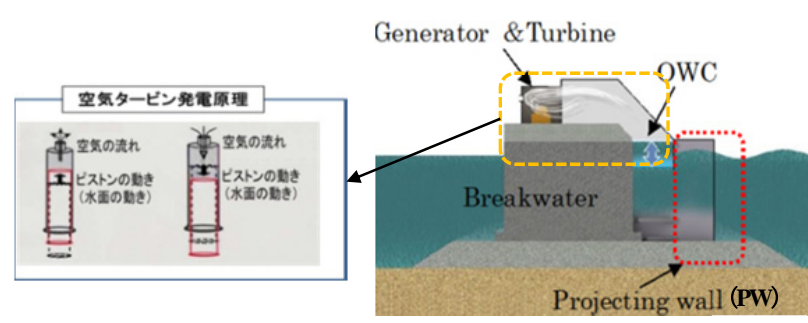

図-1 PW-OWCのイメージ図 


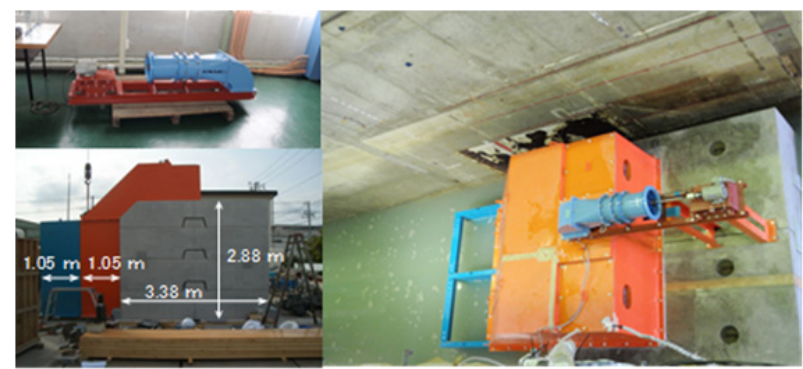

図-2１/6.7モデルによる水槽実験

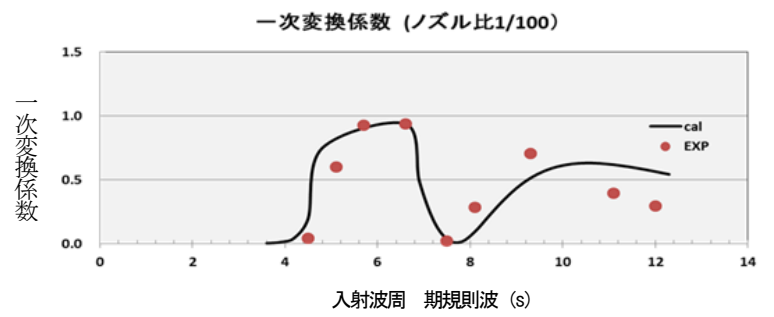

図-3 防波堤設置モデルによる一次変換係数

表-1＼cjkstart検討対象にした防波堤設置型発電装置

\begin{tabular}{|c|r|}
\hline 空気室長さ: $\mathrm{La}(\mathrm{m})$ & 7.0 \\
\hline 空気室幅 : B0 $(\mathrm{m})$ & 11.6 \\
\hline 空気室開口部深さ $: \mathrm{d} \mathrm{1}(\mathrm{m})$ & 9.7 \\
\hline 水深 $: \mathrm{h}(\mathrm{m})$ & 14.6 \\
\hline PW長さ $: \mathrm{Lp}(\mathrm{m})$ & 7.0 \\
\hline 装置側面ウイングタンク幅:W $(\mathrm{m})$ & 9.6 \\
\hline
\end{tabular}

\section{3. 安全性の検討}

安全性の検証については，港湾空港技術研究所の2次 元水槽および大規模波動地盤総合水路でそれぞれ，1/25, 1/6.7 実験(図-2)により，而波性能の検証を行った.

結果, 安定性は確保されており, 設計法もこれまで の合田波圧で評価すれば問題が無いことを確認した²).

\section{4. 有孔（消波）ケーソンのエネルギーロス}

\section{（1）酒田港一線防波堤}

発電装置は，防波堤に連続設置するが，実証実験を 想定した場合， 1 基のみの設置となる。そこで，発電装 置を防波堤に単一（1基のみ）で設置した場合を想定し， 水槽実験や著者らが開発した数值計算法3) を用い特性を 確認した.シミュレーションと実験結果を図-3に示す. なお，モデル寸法は表-1の1/6.7モデルである。図より， 波周期7.5 秒程度で一次変換係数が著しく減少している ことがわかる．実験映像及びシミュレーションで検証し たところ，背後の防波堤の反射波の重畳影響でエネルギ 一変換係数が著しく低下することが判明した
（2）実証場所の変更（有孔ケーソンへの設置）

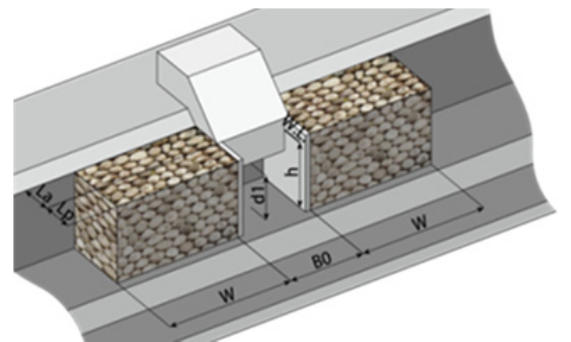

図-4＼cjkstart消波工の設置による反射波対策

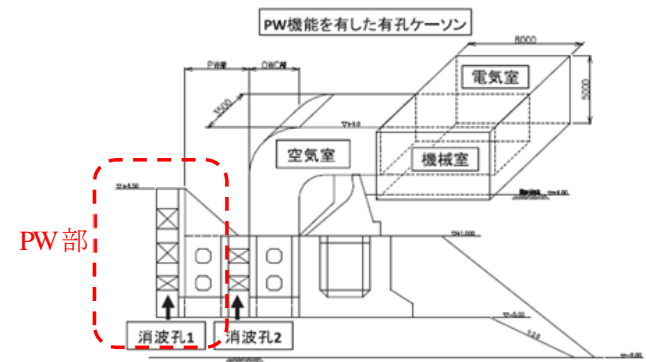

図-5 PW-OWC波力発電装置有孔ケーソン設置イメージ (構造物左が海側，右が陸側）
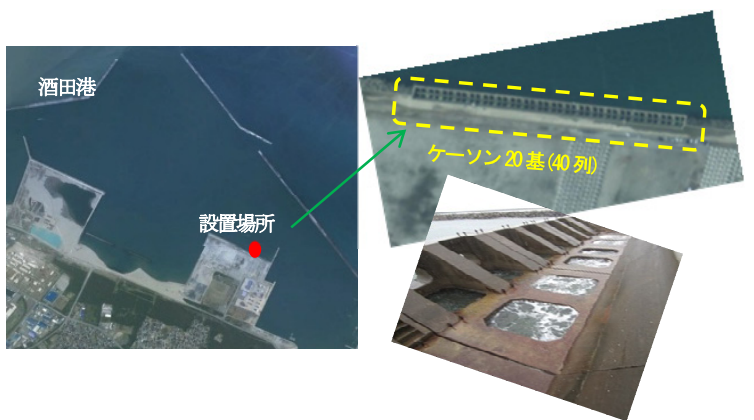

写真-1 有孔ケーソン 20 基の設置状況

上述したように防波堤や護岸など背後に壁がある構 造部に発電装置を設置する場合，背後の反射波の影響を 受け，発電装置の一次変換係数性能が低下する.

その対策として，図-4 のように装置両面の消波工設 置が必要である。しかし，このような大がかりな対策は， 莫大な費用の増大を招くとともに施工工程の制約が大き くなる久点がある. そのため, この構造での単一発電装 置による実証実験を断念した.

そこで著者らは，山形県酒田市酒田港内にある有孔 （消波）ケーソンに着目した．着目した護岸には，写真 -1 のように 20 基の有孔式消波ケーソンが整備されてお り，背後壁の反射波の影響を受けにくいと考えられた.

\section{(3) 有孔ケーソンへの設置イメージ}

消波ケーソンは，法線直角方向に連続した 2 つ遊水 室を持つ直立消波型構造物である. 有孔ケーソンは, 入射波を最初に受け入れる前部遊水室と, 水中孔でつな がっている後部遊水室とで消波部が構成されている.両 遊水室とも奥行きは各々 $3.5 \mathrm{~m}$ である. 図-5 に発電装置 
の設置イメージを示す．前部の遊水室を PW 部とし内側 の遊水室を OWC 空気室部として，PW-OWC 型装置と しての機能の発現が可能である.

\section{（4）有孔ケーソンの一次変換エネルギーロス}

有孔ケーソンは，図一に示すように消波孔 1, 2部が全 開放の大口径孔ではなく，消波を行うために小径孔とな っていることから, 一次変換係数が通常のOWCに比し て低下寸る.

また，有孔ケーソンでは，短い周期の波を対象に消波 設計がなされており，6秒以下の周期の波に対して50\% 以上エネルギーをロス寸ることから，6秒以下の周期帯 については，発電量が極めて小さくなると思われる.

酒田港の海象気象は, 夏季は静穏度が高く, 波周期も 6秒以下がほとんどであり，発電装置を一線防波堤に設 置した場合でも発電が期待できない.10４月期は荒天 日が多く，波周期6秒を超える日が多いため，有孔ケー ソンにおいて発電が可能であると推察された.

以上のことから，冬季を中心とした7秒以上の波に着 目し，発電効率を検証することとした。

有孔ケーソンによる入射波のエネルギーロスの試算を MPS法により行った。試算に用いた有孔ケーソンの孔寸 法は図一のとおりである.

$1.0 \mathrm{~m}$ 単位波高の入射波に対寸る試算結果を図-7に結果

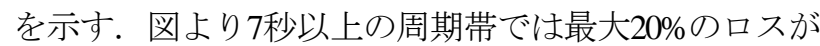
生じている。この結果は, 並行して行った水槽実験の結 果 ${ }^{1)}$ とほぼ同じ傾向を示しており，試算例は限られてい るものの，有孔ケーソンを利用した冬季の実証試験にお けるロスは，20\%程度で済むことが推定できた。

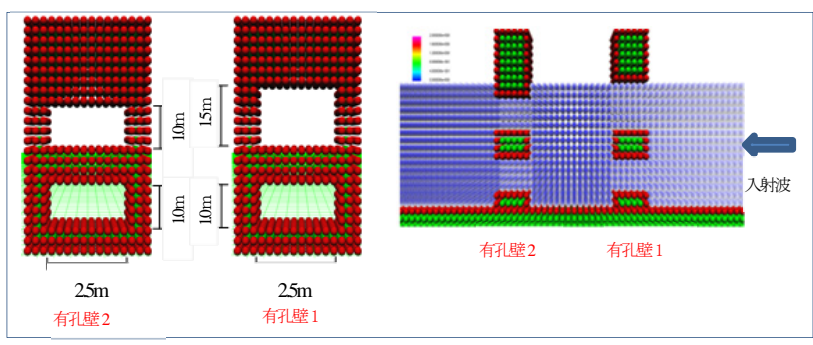

図-6 MPSに用いた施設モデル

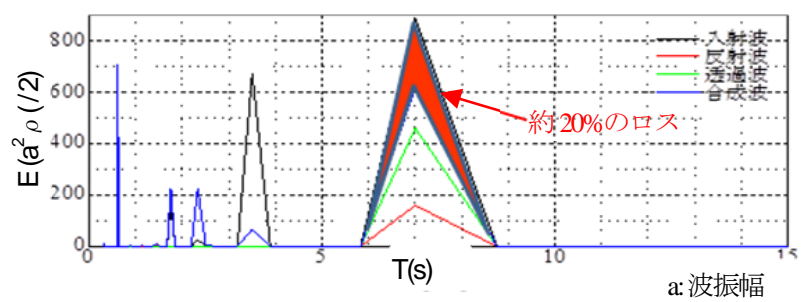

図-7ＭPSによるエネルギーの移送計算結果 ${ }^{2)}$

\section{5. 実証実験施工概要}

上記を踏まえ，実際に酒田港で実験を行う波力発電装 置の設計を行った。構造概要を図-8に示す，発電装置 の構造決定については，OWC 空気室内圧（波浪によ る），風荷重，地震時慣性力を考慮し決定した。設計 おける留意点は以下の通りである.

(1) 既設ケーソン（有孔ケーソン）の安全性. 既設構造物一の重量物搭載影響の照査

(2) 本体鋼構造部の設計 鋼構造物の而力照査

(3) カットオフ機構（安全装置）

圧抜き機構，回転ブレーキの設定

(4) タービン設計及び発電設備検討 タービン出力の検証, 発電出力の想定

(5) 現地設置・施工・管理方法の検討

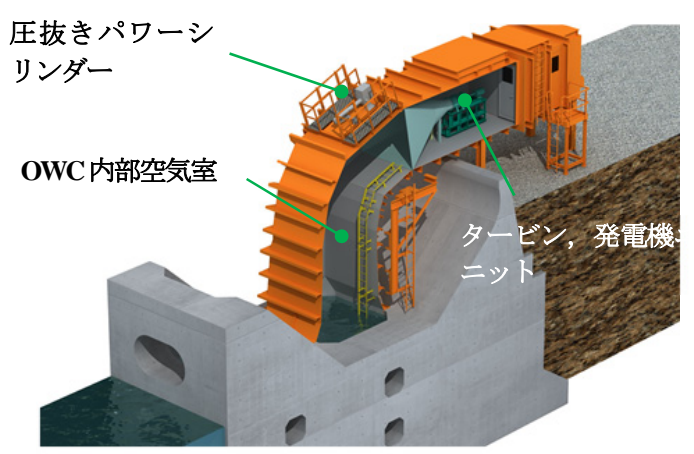

図-8 発電装置構造図
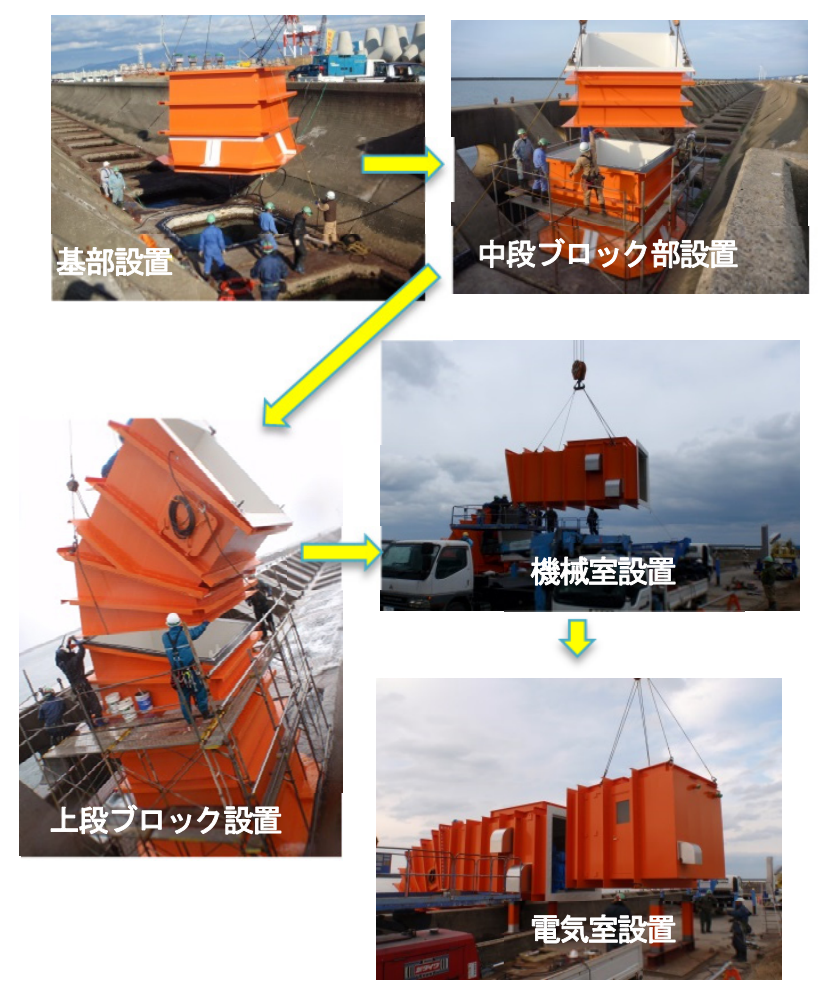

写真-2 発電装置設置状況（平成 26 年 12 月） 


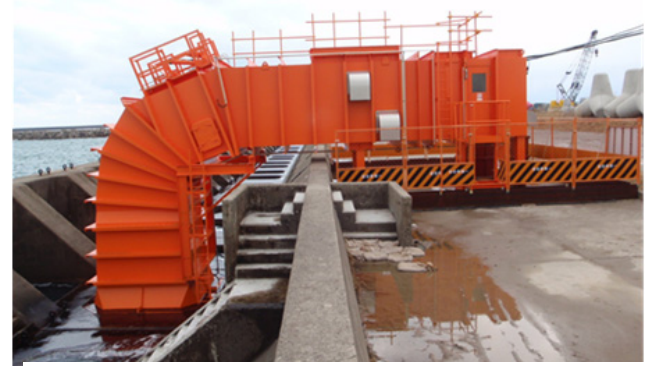

写真-3 波力発電装置完成(平成 27 年 1 月)

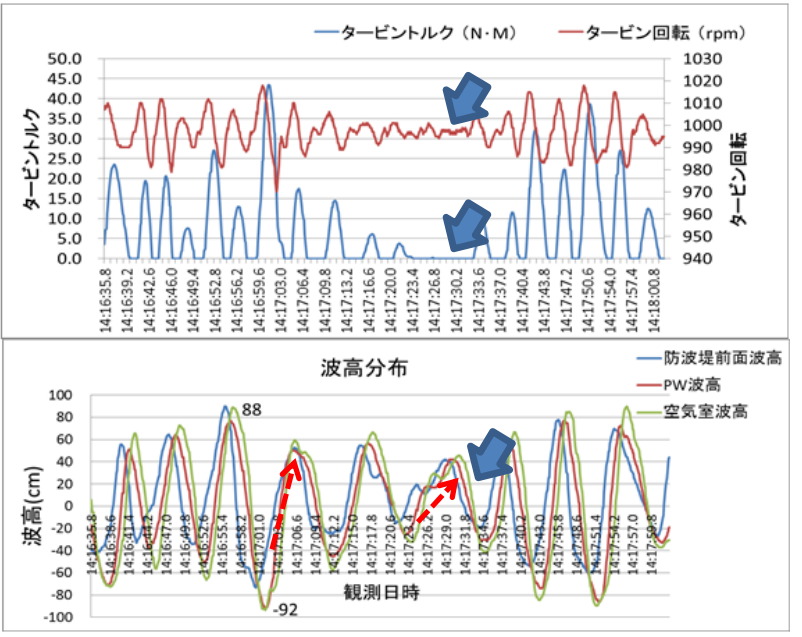

図-9 波高の時間変化（1月 31 日 14 時 16分〜18 分） と同時間帯の発生タービントルクとタービン回転数

(6) 計測項目及び計測方法（適切な計測機器配置）

(7) 実験データの取得方法の検討

平成 26 年 12 月より，酒田港において設置工事を実施 した. ユニットブロックは，トラック輸送を考慮した寸 法で設計し，富山の某鉄構メーカーで 7ブロックに分割 して製作した．搬入後，下部部材より順番に接合し設置 工事を行った．写真-2 に現地の施工状況を示す．鋼殻 ブロックの基部から順番にブロックを積み上げ，最後に 機械室，電気室を設置した．施工途中に日本海に停滞し た大型低気圧による荒天に遭遇し，1 週間工事を止めざ るを得なかったが，設置開始から約 14 日間で無事設置 を完了した（写真-3）.

\section{6. 発電状況について}

躯体完成後にタービン，発電機制御設備の整備を行い， 電気事業法における経済産業省の使用前検査合格後の平 成 27 年 1 月 17 日から連続発電（運転）を開始した.

同年 3 月 28 日までの瞬間最大発電量は $13 \mathrm{~kW}$ 程度を 観測した. 以下に平成 27 年 1 月 31 日と同年 2 月 3 日の 観測状況を示す.

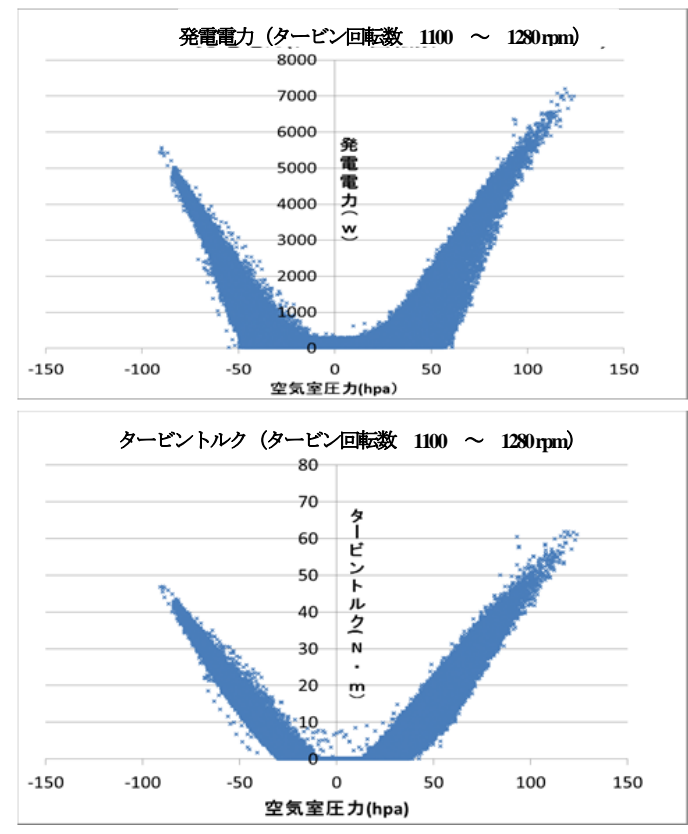

図-10 空気室圧力と発電応答（2月 13 日）

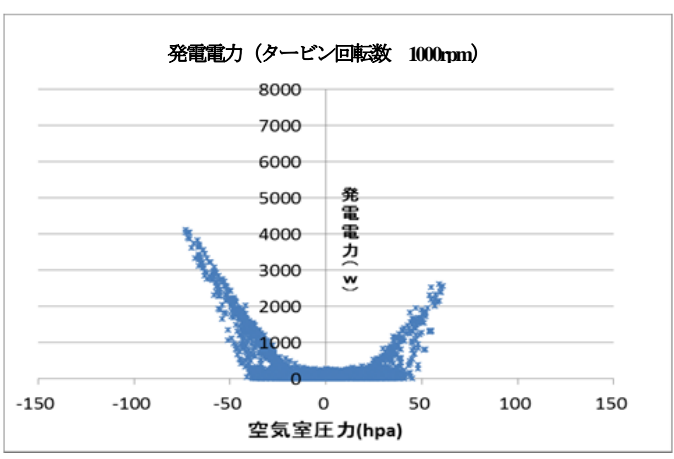

図-11 空気室圧力と発電応答特性（1月 31 日）

\section{（1） 発電特性}

往復空気流によりタービンを回転させて発電をする. 発電量はタービン回転数とタービンの発生トルク（ター ビントルク）との積になる。図-9に平成27年1月31日に 観測した波高とタービントルクの時系列変化の関係を示 す. 波高, 発電量, タービントルクの収録データピッチ は $10 \mathrm{~Hz}$ である. 水位上昇時（押し波）でも下降時(引き 波)でも，正のタービントルク值が発生しいる。しかし， 水位変化の転換時には，トルクが生じない（トルクゼロ） 時間が生じている.

矢印のポイントは，特にトルクが低い時間帯である. このときの波高は，発電してる時間帯に比べて波形が乱 れ空気室の水位変化速度が緩くなっている.

\section{(2) OWC空気室の圧カとタービン 発電量の関係}

図-10,11に平成27年2月13日と1月31日に観測された空 気室圧力とタービントルクの散布図を示す。図の左が負 圧，右が正圧すなわち左側が引き波，右側が押し波を表 


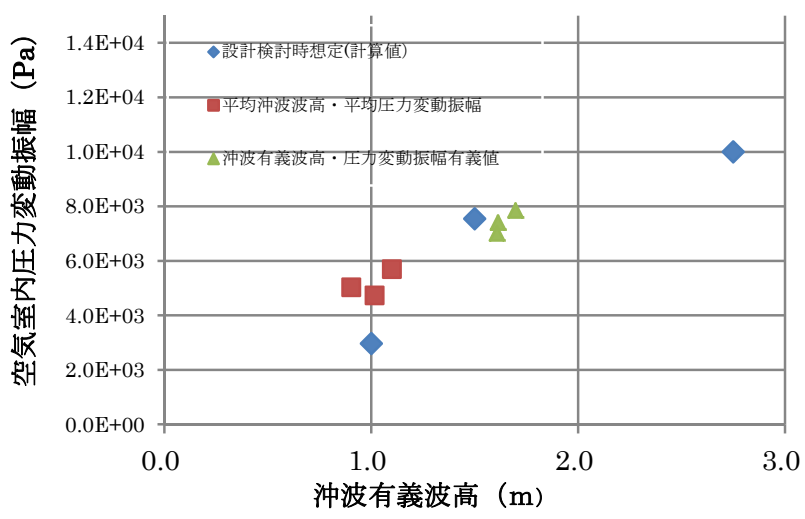

図-12 空気室内発生圧力の実測值と計算值との比較

している. 図-10では，押し波時の発生トルク>引き波 時の発生トルクとなっている. このため. 発電量も押し 波時に大きい. 一方，図-11では逆の傾向がうかがえる.

図-11の観測時では， $\mathrm{H}_{13}=0.7 \mathrm{~m}, \mathrm{~T}_{13}=5.5$ 秒, 図-10の観 測時では， $\mathrm{H}_{13}=1.9 \mathrm{~m}, \mathrm{~T}_{13}=7.1$ 秒である. 入力波（沖波） エネルギーの強弱によって, 装置の発電応答に違いがあ ることが判明した。この現象については，今後解析を進 める過程で明らかにしていく所存である.

\section{（3）一次変換特性における設計・実測の比較}

図-12に平成27年2月13日に，観測した空気室内内部の 水面変動による発生空気圧変動の実測值と計算值（設計 時想定值）の比較を示す.

図-12より一次変換におけるOWCの発生空気圧変動は, 実証試験を行う前に計算した值にほぼ一致しており，一 次変換については，事前に検討したシミュレーションプ ログラムで想定出来ることが分かった。

\section{7. まとめ}

PW-OWC型発電装置の耐波安定性を検討し，酒田港 にて実証実権を開始した. 以下の点が明らかになった.

・発電装置を防波堤や護岸に単独で設置する場合，背後 の防波堤や護岸の壁からの反射波の影響で一次変換係 数が低下する波周期帯が存在する.
・直立消波タイプの有孔ケーソンを利用したPW-OWC は，ケーソンの消波孔の影響を受けて20\%程度エネル ギーロスが生じる.

・酒田港の有孔ケーソンにPW-OWC発電装置を設置し て冬季波浪にねらいを絞った発電実験を開始した。

・発電装置の発電特性は，入射波高の強弱で応答が異な る.これについては今後引き続き検証を行う。

・一次変換に関するOWC内の空気室内の圧力変動につ いては，事前に検討したシミュレーション方法が適用 可能である。

謝辞：本研究の成果は，国立研究開発法人 新エネルギ 一・産業技術総合開発機構（NEDO）と8者の共同研究 業務の成果であり, 国立研究開発法人 海洋研究開発機 構 宮崎剛氏，(株本間組 笛木隆行氏，エイ・エス・ア イ総研(株) 太田豊彦氏には多大なるご尽力を頂いた。ま た，MPS法については，日本大学理工学部 海洋建築学 科 相田康洋氏 高畠まどか氏と共同で実施した研究成 果の一部であり，実験データのとりまとめの協力をして 頂いた．ここに敬意を表し，お礼を申し上げる.

\section{参考文献}

1) 木原一禎，細川恭史，大澤弘敬，宮崎剛，下迫健一郎， 増田光一，金谷泰邦，永田修一：ユニット型空気タービ ン式発電装置(PW-OWC) の開発 海洋開発シンポジウム 講演集 Vol39 Jun ,2014.

2）木原一禎，細川恭史，大澤弘敬，下迫健一郎，増田光一， 永田修一, 田口裕之 : 空気タービン式波力発電装置の開 発,沿岸域学会,研究討論会論文集,July, 2013.

3）宮崎剛，大澤弘敬，松浦正己，増田光一，居駒 知樹，大 森光，木原一禎，金谷 泰邦 : プロジェクティングウォー ル付振動水柱型波力発電装置の一次変換性能に関寸る検 討,日本船舶海洋工学会講演会論文集第 14 号, pp.437-440, 2013.

4) 大森光 : OWC 型波エネルギー変換装置のプロジェクティ ングウォール効果に関する研究,日本大学理工学部 海洋建 築学科, 修士論文, 2012.

\section{FIELD EXPERIMENT ON WAVE ENERGY CONVERTOR OF A PW-OWC TYPE IN THE PORT OF SAKATA,JAPAN}

Kazuysohi KIHARA,Yasushi HOSOKAWA,Hiroki OOSAWA, Kenichiro SHIMOSAKO,Kouichi MASUDA,Tomoki IKOMA, Shuuichi NAGATA and Yasukuni KANAYA 
Six private companies and research institutes \& universities jointly started a consortium research for practical use of the oscillating water column system (OWC) in 2011. Projecting-walls (PW), installed both side of the opening, were found out to make frequency dependency reduced. At the same time, hydraulic experiment for the single OWC facility installed on the line of breakwater showed sudden drop down of the efficiency of the primary conversion against a certain wave period. This occurred due to the interposition with reflection waves from the ambient surface of breakwater. Reduction of wave reflection improved this drop significantly.

The consortium with 2 new members tried a new application of PW-OWC system to the existing coastal embankment in the Sakata Port. The line of this embankment shows no bad effect of reflection waves, as the embankment has a series of two air chambers in front-back direction inside to reduce wavereflection. An experiment facility of wave power conversion was finally installed on this embankment in December, 2014. After the official safety inspection by METI, the field experiment was started to obtain the data of waves and generated electricity since January, 2015. The PW-OWC system installed on the existing facility is expected a possible design of the practical application 